U. S. DEPARTMENT OF THE INTERIOR

U. S. GEOLOGICAL SURVEY

\title{
PRELIMINARY GEOLOGIC MAP OF THE MOORPARK 7.5' QUADRANGLE, SOUTHERN CALIFORNIA: A DIGITAL DATABASE
}

\author{
Compiled by R. F. Yerkes ${ }^{1}$ and R. H. Campbell ${ }^{2}$
}

Open - File Report 97-260

This report is preliminary and has not been reviewed for conformity with U. S. Geological Survey editorial standards or with the North American Stratigraphic Code. Any use of trade, product, or firm names is for descriptive purposes only and does not imply endorsement by the U. S. Government.

This database, identified as "Preliminary Geologic Map of the Moorpark 7.5' Quadrangle, southern California: A Digital Database," has been approved for release and publication by the Director of the USGS. Although this database has been reviewed and is substantially complete, the USGS reserves the right to revise the data pursuant to further analysis and review. This database is released on condition that neither the USGS nor the U. S. Government may be held liable for any damages resulting from its use.

${ }^{1}$ Menlo Park, CA 94025

2 Reston, VA 20192 


\section{INTRODUCTION}

This Open-File report is a digital geologic map database. This pamphlet serves to introduce and describe the digital data. There is no paper map included in the Open-File report.

This digital map database is compiled from previously published sources combined with some new mapping and modifications in nomenclature. The geologic map database delineates map units that are identified by general age and lithology following the stratigraphic nomenclature of the U. S. Geological Survey. For detailed descriptions of the units, their stratigraphic relations, sources of geologic mapping, and data on exploratory wells consult Yerkes and Campbell (1995), and Yerkes and Showalter (1990). More specific information about the units may be available in the original sources.

The content and character of the database and methods of obtaining it are described herein. The geologic map database itself, consisting of three ARC coverages and one base layer, can be obtained over the Internet or by magnetic tape copy as described below. The processes of extracting the geologic map database from the tar file, and importing the ARC export coverages (procedure described herein), will result in the creation of an ARC workspace (directory) called 'mpark.'

The database was compiled using ARC/INFO version 7.0.3, a commercial Geographic Information System (Environmental Systems Research Institute, Redlands, California), with version 3.0 of the menu interface ALACARTE (Fitzgibbon and Wentworth, 1991, Fitzgibbon, 1991, Wentworth and Fitzgibbon, 1991). It is stored in uncompressed ARC export format (ARC/INFO version 7.x) in a compressed UNIX tar (tape archive) file. The tar file was compressed with gzip, and may be uncompressed with gzip, which is available free of charge via the Internet from the gzip Home Page (http://w3.teaser.fr/ jlgailly/gzip). A tar utility is required to extract the database from the tar file. This utility is included in most UNIX systems, and can be obtained free of charge via the Internet from Internet Literacy's Common Internet File Formats Webpage (http://www.matisse.net/files/formats.html). ARC/INFO export files (files with the .e00 extension) can be converted into ARC/INFO coverages in ARC/INFO (see below) and can be read by some other Geographic Information Systems, such as MapInfo via ArcLink and ESRI's ArcView (version 1.0 for Windows 3.1 to 3.11 is available for free from ESRI's web site: http://www.esri.com).

\section{OBTAINING THE DIGITAL DATA}

The digital database package can be obtained in any of three ways:

1. Sending a tape with request

A $20 \mathrm{MB}$ compressed tar file of the geologic map database and related files can be obtained by sending a tape with request and return address to:

Moorpark, CA 7.5' Geologic Database

c/o Database Coordinator

U.S. Geological Survey

345 Middlefield Road, M/S 975

Menlo Park, CA 94025 
The compressed tar file will be returned on the tape. The acceptable tape types are:

1/4 inch, $150 \mathrm{MB}$ cartridge tape

2.3 or $5.0 \mathrm{~GB}, 8 \mathrm{~mm}$ Exabyte tape.

2. Anonymous ftp over the Internet

To obtain the tar file by anonymous ftp do the following:

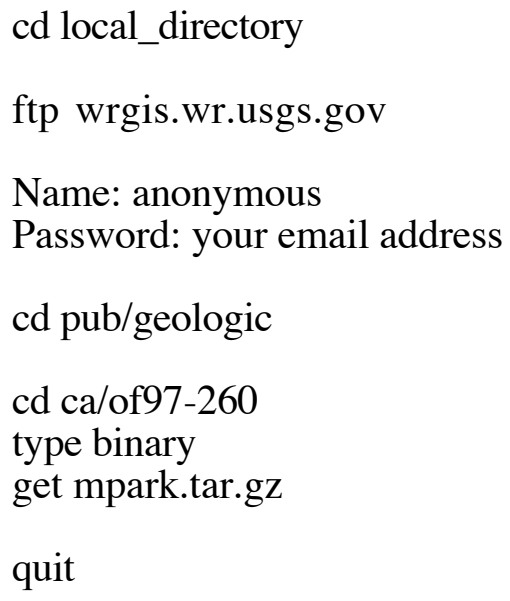

- go to a directory to receive the tar file

- make ftp connection with the USGS computer WRGIS

- use "anonymous" as your user name

- use your email address as a password

- go down to the pub/geologic directory

- go down to the open file directory

- change transfer type to binary

- copy the compressed tar file across Internet to the receiving directory

- close the ftp connection

3. From the Western Region Geologic Information Web Page.

To obtain the tar file via the World Wide Web:

The U.S. Geological Survey now supports a set of graphical pages on the World Wide Web. Digital geologic publications (including this one) can be accessed via these pages. The web page for digital geologic publications from the Western Region (including this one) is "http://wrgis.wr.usgs.gov". Once at the main page, click on 'Geologic Map Databases' under the heading 'Data Online'; next click on 'California.' Scroll down to get to the listing for this database. Set your web browser to save to a local disk and click on the link labeled 'mpark.tar.gz' to download the compressed tar file that contains the Moorpark geologic map database. 


\section{EXTRACTING THE GEOLOGIC MAP DATABASE FROM THE TAR FILE}

If you obtained the database package on tape:

put the tape in your tape drive

cd local_directory -go to a directory to receive the tar file

$\operatorname{tar} \mathrm{xvfb} / \mathrm{dev} / \mathrm{rstn} 20$

-/dev/rstn is the tape device with $\mathrm{n}$ an integer, this puts the tar file in local_directory; 20 is the block

gzip -d mpark.tar.gz size of the tar file

cd local_directory2

-makes a $85 \mathrm{MB}$ uncompressed tar file mpark.tar -go to the directory that will hold the directory mpark (if different

$\operatorname{tar} \mathrm{xvfb}$ \{path to tar from local_directory)

file\}/mpark.tar 20

-extract the mpark directory from the tar file; 20 is the block size of the tar file.

If you obtained the database package by anonymous ftp or from the web page:

$$
\begin{aligned}
& \text { gzip -d mpark.tar.gz } \\
& \text { cd local_directory2 }
\end{aligned}
$$

tar xvfb \{path to tar file\}/mpark.tar 20 -makes a $85 \mathrm{MB}$ uncompressed tar file mpark.tar -go to the directory that will hold the directory mpark (if different from local_directory)

-extract the mpark directory from the tar file.

Each of the processes described above will create a directory "mpark" that contains the ARC export files and supporting files as described below. The directory structure at this point will look like this:

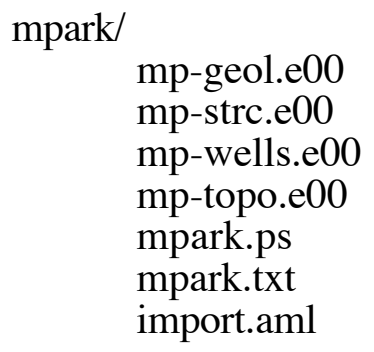

\section{GEOLOGIC MAP DATABASE CONTENTS}

The geologic map database consists of three separate layers and one base layer. Each of these layers (coverages) has been converted to uncompressed ARC/INFO export files. The $\mathrm{ARC}$ export files and the associated ARC/INFO coverages, as well as the additional digital material included in the database package, are described below: 


\begin{tabular}{|c|c|c|}
\hline $\begin{array}{l}\text { ARC/INFO } \\
\text { export file }\end{array}$ & $\begin{array}{l}\text { Resultant } \\
\text { Coverage }\end{array}$ & Description of Coverage \\
\hline mp-geol.e00 & mp-geol & Depositional contacts, faults, and unit labels \\
\hline mp-strc.e00 & mp-strc & Fold axes, strike and dip information \\
\hline mp-wells.e00 & mp-wells & $\begin{array}{l}\text { Exploratory oil wells; supporting data given } \\
\text { in Yerkes and Campbell (1995), and Yerkes } \\
\text { and Showalter (1990). }\end{array}$ \\
\hline mp-topo.e00 & mp-topo & $\begin{array}{l}\text { Topographic base map taken from a scan of } \\
\text { a composite negative of the Moorpark } 7.5 \\
\text { minute quadrangle (contour interval = } 20 \mathrm{ft} \text {.) }\end{array}$ \\
\hline
\end{tabular}

ASCII text files and PostScript plot files:

mpark.ps This file.

mpark.txt A text-only file containing an unformatted version of mpark.ps

import.aml ASCII text file in ARC Macro Language to convert these ARC export files to ARC coverages in ARC/INFO.

The following directory is produced in the process of converting the export files into ARC coverages:

info/ INFO directory containing the database files that accompany each

ARC/INFO layer (coverage).

Once the ARC export coverages have been imported (see discussion below), the Moorpark (mpark) directory, or ARC workspace, will look like this:

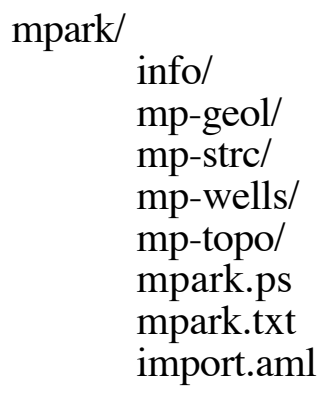

\section{CONVERTING ARC EXPORT FILES}

ARC export files are converted to ARC coverages using the ARC command IMPORT with the option COVER. In order to ease conversion and to maintain naming conventions, we have included an ASCII text file in ARC Macro Language that will convert all of the export files in the database into coverages and create the associated INFO directory. Change directories to the mpark/ directory. From the ARC command line type:

Arc: \&run import.aml 
ARC export files can also be read by some other Geographic Information Systems. Please consult your GIS documentation to see if you can use ARC export files and the procedure to import them.

\section{DIGITAL COMPILATION}

The geologic map information was digitized from stable originals of the geologic maps at 1:24,000 scale. The author manuscripts (pencil on mylar) were scanned using a monochrome scanner with a resolution of 800 dots per inch. The scanned images were vectorized and transformed from scanner coordinates to projection coordinates with digital tics placed by hand at quadrangle corners. The scanned lines were edited interactively by hand using graphical user interface ALACARTE (Fitzgibbon, 1991, Fitzgibbon and Wentworth, 1991, Wentworth and Fitzgibbon, 1991). Scanning artifacts significant for display at a scale of 1:24,000 were corrected.

\section{BASE MAPS}

The base map layer (mp-topo) was prepared by scanning a scale-stable composite negative image of the Moorpark 7.5 minute topographic map (1969 edition). The negative was scanned using a monochrome scanner with a resolution of 300 dots per inch. The raster scan was converted to a GRID in ARC/INFO. The GRID was then vectorized and reprojected into State Plane Projection using the four corner tics as reference points. The arcs in the base layer have not been attributed. The base map is provided for reference only.

\section{SPATIAL RESOLUTION}

Uses of this digital geologic map should not violate the spatial resolution of the data. Although the digital form of the data removes the constraint imposed by the scale of a paper map, the detail and accuracy inherent in map scale are also present in the digital data. The fact that this database was edited at a scale of 1:24,000 means that higher resolution information is not present in the dataset. Plotting at scales larger than 1:24,000 will not yield greater real detail, although it may reveal fine-scale irregularities below the intended resolution of the database. Similarly, where this database is used in combination with other

data of higher resolution, the resolution of the combined output will be limited by the lower resolution of these data.

\section{FAULTS AND LANDSLIDES}

This database is not sufficiently detailed or comprehensive to identify or characterize sitespecific hazards represented by faults or landslides shown; the faults shown do not take the place of fault-rupture hazard zones designated by the California State Geologist (see Hart, 1988).

\section{DATABASE SPECIFICS}

The map databases consist of ARC coverages which are stored in State Plane (California coordinate system) projection (Table 1). Digital tics define a 2.5 minute grid of latitude and longitude in the geologic coverages corresponding with quadrangle corners and internal tics. In the base map layer, the tics define a 7.5 minute grid, corresponding with quadrangle corners. 
Table 1 - Map Projection

The map is stored in State Plane projection

$\begin{array}{ll}\text { PROJECTION STATE PLANE } & \\ \text { UNITS METERS } & \begin{array}{l}\text {-on the ground } \\ \text {-Arc/Info State Plane zone } \\ \text { ZONE 3426 }\end{array} \\ \begin{array}{ll}\text { corresponding to California } \\ \text { coordinate system zone 7 }\end{array} \\ \text { PARAM NAD27 } & \text {-none }\end{array}$

The content of the geologic database can be described in terms of the lines and the areas that compose the map. Descriptions of the database fields use the terms explained in Table 2.

Table 2 - Field Definition Terms

ITEM NAME name of the database field (item)

WIDTH maximum number of digits or characters stored

OUTPUT output width

TYPE B-binary integer, F-binary floating point number,

I-ASCII integer, C-ASCII character string

N. DEC. number of decimal places maintained for

floating point numbers

\section{LINES}

The lines (arcs) are recorded as strings of vectors and are described in the arc attribute table (Table 3). They define the boundaries of the map units, the boundaries of open bodies of water, and the map boundaries. These distinctions, including the geologic identities of the unit boundaries, are recorded in the LTYPE field according to the line types listed in Tables 4 and 5. 
Table 3 - Content of the Arc Attribute Tables (MP-GEOL.AAT, MP-STRC.AAT)

\begin{tabular}{|c|c|c|c|c|c|}
\hline ITEM NAME & WIDTH & OUTPUT & TYPE & N. DEC & \\
\hline FNODE\# & 4 & 5 & B & \multirow{10}{*}{3} & $\begin{array}{l}\text { starting node of arc } \\
\text { (from node) }\end{array}$ \\
\hline TNODE\# & 4 & 5 & B & & $\begin{array}{l}\text { ending node of arc } \\
\text { (to node) }\end{array}$ \\
\hline LPOLY\# & 4 & 5 & B & & $\begin{array}{l}\text { polygon to the left of } \\
\text { the arc }\end{array}$ \\
\hline RPOLY\# & 4 & 5 & B & & $\begin{array}{l}\text { polygon to the right } \\
\text { of the arc }\end{array}$ \\
\hline LENGTH & 4 & 12 & $\mathrm{~F}$ & & length of arc in meters \\
\hline$<$ coverage $>\#$ & 4 & 5 & B & & $\begin{array}{l}\text { unique internal } \\
\text { control number }\end{array}$ \\
\hline$<$ coverage $>$-ID & 4 & 5 & B & & $\begin{array}{l}\text { unique identification } \\
\text { number }\end{array}$ \\
\hline LTYPE & 35 & 35 & $\mathrm{C}$ & & line type (see Table 4 ) \\
\hline SEL & 1 & 1 & I & & user defined field used \\
\hline SYMB & 3 & 3 & I & & $\begin{array}{l}\text { user defined field used } \\
\text { to save symbol } \\
\text { assignments (such } \\
\text { as color) }\end{array}$ \\
\hline
\end{tabular}

Table 4 - Line Types Recorded in the LTYPE Field (MP-GEOL.AAT)

contact, certain contact, approx. located contact, inferred

fault, approx. located

fault, concealed map boundary, certain normal fault, approx. located normal fault, concealed

Table 5 - Line Types Recorded in the LTYPE Field (MP-STRC.AAT)

f.a., anticline, approx. located

f.a., anticline, concealed

f.a., syncline, approx. located

f.a., syncline, concealed

\begin{abstract}
AREAS
Map units (polygons) are described in the polygon attribute table (Table 6) The identities of the map units from compilation sources are recorded in the PTYPE field by map label (Table 7). For a full description of the map units see Yerkes and Campbell (1995).
\end{abstract}


Table 6 - Content of the Polygon Attribute Tables (MP-GEOL.PAT)

ITEM NAME WIDTH OUTPUT TYPE N. DEC

\begin{tabular}{|c|c|c|c|c|c|}
\hline AREA & 4 & 12 & $\mathrm{~F}$ & 3 & $\begin{array}{l}\text { area of polygon in square } \\
\text { meters }\end{array}$ \\
\hline PERIMETER & 4 & 12 & $\mathrm{~F}$ & 3 & length of perimeter in meters \\
\hline$<$ coverage $>\#$ & 4 & 5 & B & & $\begin{array}{l}\text { unique internal control } \\
\text { number }\end{array}$ \\
\hline$<$ coverage $>$-ID & 4 & 5 & B & & unique identification number \\
\hline PTYPE & 35 & 35 & $\mathrm{C}$ & & unit label (see Table 7) \\
\hline SEL & 1 & 1 & I & & $\begin{array}{l}\text { user defined field used to save } \\
\text { a selected set }\end{array}$ \\
\hline SYMB & 3 & 3 & I & & $\begin{array}{l}\text { user defined field used to save } \\
\text { symbol assignments (such as } \\
\text { color) }\end{array}$ \\
\hline
\end{tabular}

$\begin{array}{lll}\text { QTp } & \text { Qls? } & \text { Tm? } \\ \text { Qal } & \text { Qs } & \text { Ts } \\ \text { Qao } & \text { Qsc } & \text { Ts? } \\ \text { Qf } & \text { Qsp } & \text { Tt } \\ \text { Qfo } & \text { Qt } & \text { Tv } \\ \text { Qfp } & \text { Tc } & \\ \text { Qls } & \text { Tm } & \end{array}$

\section{POINTS}

Point information (strikes and dips, well localities) is recorded as coordinate and related information and is described in the Point Attribute Table (Tables 8 and 10).

Table 8 - Content of the Point Attribute Tables (MP-STRC.PAT)

\section{ITEM NAME WIDTH OUTPUT TYPE N. DEC}

\begin{tabular}{|c|c|c|c|c|}
\hline AREA & 4 & 12 & $\mathrm{~F}$ & not used \\
\hline PERIMETER & 4 & 12 & $\mathrm{~F}$ & not used \\
\hline$<$ coverage >\# & 4 & 5 & B & $\begin{array}{l}\text { unique internal control } \\
\text { number }\end{array}$ \\
\hline$<$ coverage $>$-ID & 4 & 5 & B & unique identification number \\
\hline PTTYPE & 35 & 35 & $\mathrm{C}$ & point type (see Table 9) \\
\hline DIP & 3 & 3 & I & dip angle in degrees \\
\hline STRIKE & 3 & 3 & I & strike angle in degrees \\
\hline SEL & 1 & 1 & I & $\begin{array}{l}\text { user defined field used to } \\
\text { save a selected set }\end{array}$ \\
\hline SYMB & 3 & 3 & I & $\begin{array}{l}\text { user defined field used to } \\
\text { save symbol assignments } \\
\text { (such as color) }\end{array}$ \\
\hline
\end{tabular}

Table 9 - Point Types (mp-strc)

Bedding 
Table 10 - Content of the Point Attribute Tables (MP-WELLS.PAT)

ITEM NAME WIDTH OUTPUT TYPE N. DEC

\begin{tabular}{|c|c|c|c|c|}
\hline AREA & 4 & 12 & $\mathrm{~F}$ & not used \\
\hline PERIMETER & 4 & 12 & $\mathrm{~F}$ & not used \\
\hline$<$ coverage $>\#$ & 4 & 5 & B & $\begin{array}{l}\text { unique internal control } \\
\text { number }\end{array}$ \\
\hline$<$ coverage $>$-ID & 4 & 5 & B & $\begin{array}{l}\text { unique identification } \\
\text { number }\end{array}$ \\
\hline PTTYPE & 35 & 35 & $\mathrm{C}$ & point type \\
\hline SAMNO & 35 & 35 & $\mathrm{C}$ & sample number \\
\hline SEL & 1 & 1 & I & user defined field used \\
\hline SYMB & 3 & 3 & I & $\begin{array}{l}\text { to save a selected set } \\
\text { user defined field used to } \\
\text { save symbol assignments } \\
\text { (such as color) }\end{array}$ \\
\hline
\end{tabular}

\section{ACKNOWLEDGMENTS}

R. H. Campbell, Reston, VA assisted in field interpretations and compilation; P. K. Showalter and C. M. Wentworth supplied critical custom programming; and S. E. Graham updated supporting files for completeness and consistency and prepared this report. 


\section{REFERENCES}

Fitzgibbon, T.T., 1991, ALACARTE installation and system manual (version 1.0): U.S. Geological Survey, Open-File Report 91-587B.

Fitzgibbon, T.T., and Wentworth, C.M., 1991, ALACARTE user interface - AML code and demonstration maps (version 1.0): U.S. Geological Survey, Open-File Report 91-587A.

Hart, E.W., 1988, Fault-rupture hazard zones in California; Alquist-Priolo Special Studies Zones Act of 1972 with index to special studies zones maps: California Division of Mines and Geology Special Publication 42.

Wentworth, C. M., and Fitzgibbon, T. T., 1991, ALACARTE user manual (version 1.0): U. S. Geological Survey Open-File Report 91-587C.

Yerkes, R. F., and Campbell, R. H., 1995, Preliminary geologic map of the Moorpark 7.5' quadrangle, southern California: U. S. Geological Survey Open-File Report 95-827.

Yerkes, R. F., and Showalter, 1990, Exploratory wells drilled in the Los Angeles, California 1:100,000 quadrangle, southern California: U. S. Geological Survey Open-File Report 90-627. 